\title{
Thalidomide surveillance and pharmacovigilance in Brazil - an overview
}

\section{Vigilância e farmacovigilância da talidomida no Brasil - uma visão geral}

\author{
Lisiane Freitas Leal ${ }^{*}, 1$ \\ Daniel Marques Mota" (iD
}

I Department of Epidemiology, Biostatistics and Occupational Health, McGill University, Montreal, QC, Canada.

" Agência Nacional de Vigilância Sanitária (Anvisa), Brasília, DF, Brasil.

\section{* E-mail: lisianeleal@gmail.com}

Received: Apr 28, 2020

Approved: Jun 22, 2020

\begin{abstract}
Introduction: The thalidomide is probably the best-known teratogenic drug and still results in cases of severe physical deformities in children born in Brazil. Objective: To present the overall context of surveillance and pharmacovigilance of thalidomide in Brazil. Method: This article presents a narrative review of current literature concerning thalidomide regulation, policies, and pharmacovigilance in Brazil. Results: New cases of congenital abnormalities whose phenotype is compatible with thalidomide embryopathy were identified in the last ten years, while the approval of thalidomide for new indications was recently updated. The mechanisms of diagnosing thalidomide embryopathy are complex, remaining the challenge in distinguishing this condition from other congenital abnormalities. The increasing number of thalidomide users in Brazil is correlated with the occurrence of embryopathy and the real extension of the rationality of its use is largely unknown. Additionally, our pharmacovigilance and surveillance systems are predominantly based on voluntary reports, issues that remains over the years. Conclusions: The policies have improved over the years to prevent the fetus from being exposed to thalidomide, and current regulation establishes rules for controlling its distribution, prescription, dispensation, and use. Brazilian surveillance system is manual and pharmacovigilance is supported by voluntary reports. The failure of the system to properly control the thalidomide use and its effects might lead to serious consequences to the community; therefore, this subject deserves constant attention.
\end{abstract}

KEYWORDS: Brazilian Health Surveillance Agency; Fetal Diseases; Pharmacovigilance; Product Surveillance; Postmarketing; Thalidomide

\section{RESUMO}

Introdução: A talidomida é, provavelmente, a droga teratogênica mais conhecida e ainda resulta em graves deformidades físicas em crianças nascidas no Brasil. Objetivo: Apresentar o contexto geral de vigilância e farmacovigilância da talidomida no Brasil. Método: Este artigo apresenta uma revisão narrativa da literatura atual sobre regulação, políticas e farmacovigilância da talidomida no Brasil. Resultados: Novos casos de anormalidades congênitas cujo fenótipo é compatível com a embriopatia por talidomida foram identificados nos últimos dez anos, enquanto a aprovação da talidomida para novas indicações foi recentemente atualizada. Os mecanismos de diagnóstico da embriopatia por talidomida são complexos, permanecendo o desafio de distinguir essa condição de outras anormalidades congênitas. 0 crescente número de usuários de talidomida no Brasil está correlacionado com a ocorrência de embriopatia e a real extensão da racionalidade de seu uso é amplamente desconhecida. Além disso, nossos sistemas de farmacovigilância e vigilância se baseiam predominantemente em notificações voluntárias, questões que permanecem ao longo dos anos. Conclusões: As políticas evoluiram ao longo dos anos para impedir que fetos fossem expostos à talidomida, e a regulamentação atual estabelece regras para controlar sua distribuição, prescrição, dispensação e uso. 0 sistema de vigilância brasileiro é manual e a farmacovigilância é apoiada por notificações voluntárias. A falha do sistema em controlar adequadamente o uso da talidomida e seus efeitos pode levar a sérias consequências para a comunidade, portanto, esse assunto merece atenção constante.

PALAVRAS-CHAVE: Agência Nacional de Vigilância Sanitária; Doenças Fetais; Farmacovigilância; Vigilância de Produtos Comercializados; Talidomida 


\section{INTRODUCTION}

The thalidomide, probably the best well-known teratogenic drug, still results in cases of severe physical deformities in children born in Brazil ${ }^{1,2}$. The policies have improved over the years to prevent the fetus exposure,,$^{3,4,5}$ and current regulation establishes rules for controlling its distribution, prescription, dispensation, and use $\mathrm{e}^{3,4}$.

In our country, the pharmacovigilance system is supported by voluntary notifications, probably capturing less than $10 \%$ of the adverse drug events $(A D E)^{6}$. In fact, under-reporting is an important issue concerning rare event ${ }^{7}$, one of the concerns related with thalidomide exposure during pregnancy.

Policies, pharmacovigilance and educational initiatives are provided by the Brazilian Health Regulatory Agency (in Portuguese, Agência Nacional de Vigilância Sanitária - Anvisa) along with the Ministry of Health. Additionally to the national pharmacovigilance system, the Latin American Collaborative Study of Congenital Malformations (ECLAMC) ${ }^{8}$, a Hospital Network in Latin American countries that registers infants with malformations, performs an important role for thalidomide surveillance.

The passive surveillance due to voluntary reports currently available in Brazil poses a challenge in identifying possible birth defects associated with the thalidomide use ${ }^{9}$, and, consequently, with the delay in identifying the reasons related to accidental exposure during pregnancy. In addition to the voluntary reports, the complexity and time spent on attributing the diagnosis of thalidomide embryopathy (TE), remains a challenge for the healthcare system and population. Therefore, although not new, this topic deserves to be revisited, considering improvements in surveillance and pharmacovigilance are still needed. We aim to review the overall context of the thalidomide policies, surveillance, and their implication in public health in Brazil. In addition, we aim to propose improvements for future surveillance.

\section{METHOD}

This article presents a narrative review of current literature concerning thalidomide regulation, policies, and pharmacovigilance in Brazil. Considering that the documents related to legislation and pharmacovigilance processes are published as technical literature, i.e. reports and legislation, the process of screening literature was carried out in a non-systematic way.

The information selected and presented here was based on: (i) Reviewing the timeline of policies and regulation of thalidomide in Brazil through the Ministry of Health website; (ii) Searching for scientific articles published in Scientific Electronic Library Online (SciELO) and PubMed presenting Brazilian data on thalidomide use and thalidomide embryopathy; and (iii) Searching for non-scientific literature (reports in newspapers and magazines) for fulfilling other gaps in information and recent updates.

\section{RESULTS AND DISCUSSION}

\section{The thalidomide regulation in Brazil - an overview}

Worldwide, the timeline of thalidomide history is well described ${ }^{2,10,11,12}$. In Brazil, thalidomide was first approved in 1958 for the treatment of sleep disorders and as sedative medication. In 1962, with the recognition of teratogenesis, the Brazilian government cancelled the approval of thalidomide-based drugs, but the act was not formally established until 1964. According to the Brazilian Association of Patients with Thalidomide Syndrome (in Portuguese, Associação Brasileira de Portadores de Síndrome de Talidomida - ABPST), the drug was indeed withdrawn from the market in $1965^{13}$. In the $1960 \mathrm{~s}$, the use of thalidomide in Brazil was regulated by the Ministry of Health for the treatment of Hansen's Erythema Nodosum - ENH ${ }^{12}$. This therapeutic indication came after the international discovery that the drug was effective for the treatment of leprosy erythema. From 1964 to recent days, the drug has been largely studied and new indications have been evaluated ${ }^{14,15}$ and approved ${ }^{16}$, along with the efforts to regulate its commercialization.

Currently, thalidomide is approved for a list of diseases, as shown in Table 1. The whole list of documents that regulates thalidomide in Brazil is available on the Ministry of Health website ${ }^{17}$.

The Ordinance No. 3,125, dated October $7^{\text {th }}, 2010$, has approved the leprosy surveillance, care, and control guidelines ${ }^{18}$, and there are four other protocols published by the Ministry of Health in which the thalidomide is indicated ${ }^{19,20,21,22}$. For none of them, though, the drug is recommended as a first choice, and its use in childbearing age women is restricted to special situations and should follow strict evaluation before prescription ${ }^{17}$.

Policies were improved in 2011 through the publication of Resolution No. 11, dated March 22 ${ }^{\text {nd }}, 2011^{4}$. Several restrictions were included, in order to cover prescription and other stages of pharmaceutical assistance. The first was related to the methods of contraception. The second was to list all diseases authorized for thalidomide treatment. The third was related to the orientations for requesting exceptional authorization for drug use, for example, cases of women in childbearing age. The fourth was related to documentation, including improvement and unification of the clarification and responsibility terms. Modifications that would simplifying bureaucracy and guidance to the patient care. The fifth was related to packaging, including the image of a child affected by thalidomide in the cartridge, an explanatory leaflet for the healthcare professional, and a black box warning in the package insert. The sixth was about adverse reactions report. The seventh treated the criteria for registering prescribers and users. The final one was related to changes in prescription control, before controlled only by sequential numbers. Guidance on return and disposal of medication was also included, in addition to the inclusion of details of criminal liability due to misuse. 
Table 1. Indications for thalidomide treatment in Brazil.

\begin{tabular}{|c|c|}
\hline Diseases & ICD-10* \\
\hline Leprosy: Erythema nodosum or type II leprosy reaction & A 30.0 \\
\hline STD/AIDS: Idiopathic aphthous ulcers in patients with HIV/AIDS & B 23.8 \\
\hline \multicolumn{2}{|l|}{ Chronic degenerative diseases: } \\
\hline Systemic lupus erythematosus & M 32 \\
\hline Discoid lupus erythematosus & L 93.0 \\
\hline Subacute cutaneous lupus erythematosus & L 93.1 \\
\hline Graft versus host disease & T 86.0 \\
\hline Multiple myeloma & C 90.0 \\
\hline \multicolumn{2}{|c|}{ Myelodysplastic syndrome (MDS): in patients refractory to erythropoietin } \\
\hline Refractory anemia without ring sideroblasts; & D 46.0 \\
\hline Refractory anemia with ring sideroblasts; and & D 46.1 \\
\hline Unspecified refractory anemia & D 46.4 \\
\hline
\end{tabular}

STD: sexually transmitted diseases; AIDS: acquired immunodeficiency syndrome; HIV: human immunodeficiency virus.

* International Classification of Diseases (ICD) - 10th revision

Source: Resolution - RDC No. 50, November 11, $2015^{16}$.

The onward regulation, additionally to national meetings on thalidomide control ${ }^{23}$, are great initiatives, but probably not enough to tackle the ongoing problems of the increasing use of the drug.

A review of thalidomide pharmacovigilance: 1966 to present with a focus on recent cases

The victims of congenital anomalies caused by thalidomide are classified according to generations. The First Generation accounts by those affected before the drug banishment; the Second Generation by those affected from 1966 to 1998, after the new release of the substance; the Third Generation, by the new victims between 2005 and 2010, despite the control instituted by the Brazilian Ministry of Health; and the recent cases, called Fourth and Fifth Generation and including those identified after $2010^{24}$.

TE diagnosis is a challenge due to common characteristics shared by other congenital anomalies. Also, a causal association between the thalidomide use and the occurrence of the embryopathy is not always found, requiring an in-depth study of all other factors that could be related with the disease occurrence ${ }^{2}$. A thalidomide-like phenotype inclusion in the routine surveillance of birth defects, that consisted of any bilateral upper and/or lower limb reduction defect of the preaxial and/or phocomelia types, was recommended in $1996^{25}$. Later, Vianna et al. included additional characteristics, such as amelia (complete absence of one or more limbs) for surveillance studies carried out on the data generated by ECLAMC ${ }^{26}$. This system became proactive in assessing TE phenotype ${ }^{2}$ only in 2007, and includes all babies born in hospitals that are part of ECLAMC.

In Brazil, any adverse event and technical complaint related to the thalidomide use should be immediately notified to Anvisa. The responsibility for reporting is shared by health professionals and health facilities ${ }^{16}$, relying in a voluntary and probably under-reported system.

Between 2008 and 2018, the Notivisa was the national-level system for receiving reports of suspected ADE in Brazil, supporting pharmacovigilance actions. During this period, only 28 reports related to thalidomide were recorded, none of them TE suspected $^{23}$. The main adverse reactions reported were peripheral neuropathy, drowsiness and gastrointestinal disorders that are expected in thalidomide users.

In 2011, a Brazilian group evaluated the implementation of a proactive surveillance system to identify birth defects compatible with $\mathrm{TE}^{26}$. Two cases were compatible with TE and authors highlighted the importance of active surveillance. Leprosy is an endemic disease and it is the most prevalent condition in which patients receive thalidomide prescription ${ }^{26}$, an important factor to take into account regarding active surveillance.

For our knowledge, no official updated estimates of new cases have been published recently. According to our search, we show in Table 2 the cases of embryopathy supposedly associated with thalidomide, which were registered and classified as third-generation patients. There are many factors that delay investigations to attribute causality to TE and thalidomide exposure. In Brazil, cases under investigation prevent effective actions since mechanisms that led thalidomide exposure in pregnancy were not clarified and treated ${ }^{23}$.

Most of Brazilian cases are identified by the ECLAMC 8 ; however, despite its importance, it covers just $5 \%$ of all children born in our country ${ }^{1}$.

According to the brief description of the cases presented during the Anvisa meeting in $2016^{23}$, gaps in the whole pharmaceutical assistance process can be identified, regardless of the diagnostic criteria9,27. 
Thalidomide pharmaceutical assistance and consumption, how to effectively control?

Brazil is the fifth most populated country in the world; its population was estimated in 2018 in 209,186,802 inhabitants ${ }^{28}$.

Thalidomide $100 \mathrm{mg}$ is part of the National List of Essential Medicines (Rename), which is centrally purchased by the Ministry of Health. For the treatment of the aforementioned diseases, the Ministry of Health provided for the acquisition and distribution of 5,433,600 thalidomide tablets $100 \mathrm{mg}$ to $27 \mathrm{Bra}$ zilian states in $2018^{29}$.

The Clinical use and control of the dispensing of thalidomide in Brasília, Federal District, Brazil, from 2001 to 2012 was described by Paumgartten ${ }^{15}$ but not new studies showing such numbers were published since then.

The most recent study showed the distribution of drug dispensing, the prevalence of the target disease, and characteristics of the phenotype of TE, at the population level ${ }^{1}$. A correlation between thalidomide and a phenotype of TE occurrence was showed. Unfortunately, their data covered just 5 years, and no further results of surveillance were published since the approval for new diseases. Moreover, for our knowledge, no active control has been made for a drug dispensed in Brazil, which is manufactured by a governmental foundation (in Portuguese - Fundação Ezequiel Dias - Funed).

Recommendations provided by the World Health Organization $(\mathrm{WHO})^{27}$ seem not to have changed over the years, remaining the gap in thalidomide surveillance and the occurrence of new cases of TE. According to the WHO, better regulation and communication are key to prevent future cases; nevertheless, uncertainties remain in how effective the current measures are followed in our country. WHO specialists highlighted crucial efforts in ensuring the prescription and dispensing of thalidomide, avoiding a new wave of fetal malformations, either during a clinically indicated use or by accidental or off-label use by unintended users ${ }^{2}$. In our country, 3 up to 7 cases were due to incorrect use ${ }^{2}$. In fact, it is unknown how to avoid the unwary third parties with trivial, off-label indications for its use in which education seems not preventing such exposure.

Currently, we are not gathering complete and contemporary information on the incidence and prevalence of thalidomide fetotoxicity, a reality that needs to be changed. Active surveillance, in-depth knowledge of the population who is under treatment, as well as the tight control of the pharmaceutical assistance system are keys points in reducing avoidable non-intended exposures during pregnancy. Strict control of dispensing is needed and how this control is made across the country should be analyzed. It is unacceptable that cases are identified just after accidental exposure.

Concerning the distribution, the control is established by Ordinance No. 344, dated May 12, $1998^{3}$ (regulated controlled substances in Brazil) and by the Resolution No. 11, dated March 22, $2011^{4}$, previously presented. Pharmaceutical assistance and sanitary surveillance subsystems gaps, in state- and municipal-level, cannot be accepted.

For most of the cases listed in Table 2, the drug was used for leprosy treatment; it is reasonable to assume that the lack of control was present additionally to the lack of local epidemiological surveillance.

Table 2. Brief description of the cases of embryopathy allegedly associated with thalidomide exposure. Brazil, 2005-2018.

\begin{tabular}{|c|c|c|c|}
\hline Region & Year & Federation unity & Cases description and thalidomide exposure report \\
\hline North & 2005 & Rondônia & $\begin{array}{l}\text { The baby was born in Rondônia, without arms and legs. The mother took } \\
\text { thalidomide used by her husband to treat leprosy. }\end{array}$ \\
\hline \multirow[t]{4}{*}{ Northeast } & 2006 & Maranhão & $\begin{array}{l}\text { The child was born in Maranhão without his arms. The mother had leprosy and } \\
\text { was prescribed thalidomide without information on the methods of contraception } \\
\text { she should adopt. Healthcare providers only suspected when she was getting the } \\
\text { BCG vaccine and, as the baby had no arm, the case was then reported to the } \\
\text { Ministry of Health. }\end{array}$ \\
\hline & 2010 & Maranhão & $\begin{array}{l}\text { Birth of a child without arms and legs in Cajari municipality, the mother had } \\
\text { already been treated for leprosy incorrectly. In } 2009 \text {, she got Thalidomide } \\
\text { illegally at the clinic and self-medicated. }\end{array}$ \\
\hline & 2011 & Maranhão & $\begin{array}{l}\text { An ongoing investigation of } 1 \text { other } 12 \text {-year-old child in Cajari suspected of being } \\
\text { malformed due to mother's use of Thalidomide. }\end{array}$ \\
\hline & 2012 & Piauí & $\begin{array}{l}\text { Birth of a child with thalidomide syndrome in Barras, Piauí, due to the use of } \\
\text { thalidomide by his mother, a leprosy patient. Research has identified that: } \\
\text { i) There was no correct prescription; ii) The mother's statement of clarification } \\
\text { was not signed; iii) Mother claimed to be using contraception; and iv) Insufficient } \\
\text { records of contraceptive administration. }\end{array}$ \\
\hline South & 2006 & Rio Grande do Sul & $\begin{array}{l}\text { A 17-year-old girl used her mother's thalidomide for myeloma treatment. } \\
\text { She gave birth to twins, both malformed, one died after birth. }\end{array}$ \\
\hline Southeast & 2018 & Minas Gerais & $\begin{array}{l}\text { Pregnancy of a leprosy patient on thalidomide reported. There was spontaneous } \\
\text { termination of pregnancy due to severe malformations. }\end{array}$ \\
\hline
\end{tabular}

BCG: Bacillus Calmette-Guérin.

Source: Anvisa, $2018^{23}$ 
Regulation related to prescription also exists. Physicians should prescribe thalidomide in a special numbered form (Thalidomide Prescription Notification), according to Law No. 10.651, dated April 16, 20035. The absence of doctors who properly registered to prescribe thalidomide in the local health system might favor the occurrence of cases of TE.

Beyond the physician, the pharmacist has a great responsibility in both orienting and dispensing thalidomide, representing the last checkpoint to avoid thalidomide exposure during pregnancy. The pharmacist is responsible for recording thalidomide

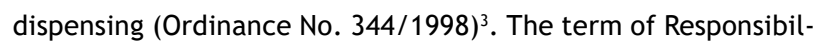
ity (TR) is mandatory, as well as the dispensing register in order to inform the local health system. Adequate guidance on the teratogenic effects of the medication should be provided. The pharmacist strengthens the control measures defined by the current normative acts.

Women of childbearing age who use thalidomide to treat leprosy should use contraceptive methods and pregnancy tests are required, before and after thalidomide treatment initiation. The TR should be signed upon receipt of the drug by the user and it is a proof that the patient was properly advised and received guidance for the thalidomide safety.

The inspection and control of all stages of distribution, prescription, dispensing and use should be strictly controlled by pharmaceutical assistance and the local health surveillance system. A specific record book for thalidomide control should be formally opened by the Sanitary Surveillance. It is one of the evidences that are required in the sanitary surveillance inspection process. The lack of records of thalidomide dispensing, showing an inventory control, is an infraction to the Ordinance No. $344 / 1998^{3}$.

Policies are properly published and reviewed, remaining the question about who is effectively controlling this process across the country. In Brazil, what we observe is a process of control essentially manual, which is allied to a passive pharmacovigilance system. A system that is fated to present numerous flaws and that requires immediate actions.

Epidemiologic surveillance of congenital anomalies in other countries and future directions in Brazil

In Europe, the populational network for epidemiologic surveillance of congenital anomalies (EUROCAT) covers $29 \%$ of the European population, facilitating the identification of teratogenic exposures and assessing the impact of primary prevention and prenatal screening policy and practice at a population level ${ }^{30}$.

In the United States of America, the National Center on Birth Defects and Developmental Disabilities (NCBDDD) strives to advance the health and well-being of the nation's most vulnerable populations ${ }^{31}$. Also, the FDA's Sentinel Initiative is an example of monitoring proactively the safety of medical products after they have reached the market and complements the Agency's existing Adverse Event Reporting System ${ }^{32}$.
In Canada, the Canada Vigilance Program operates based on adverse reaction reports submitted by healthcare professionals and consumers. The Canadian Congenital Anomalies Surveillance Network (CCASN) is under the umbrella of the Canadian Perinatal Surveillance System (CPSS) and, in addition to this surveillance system, Health Canada formed the Drug Safety and Effectiveness Network (DSEN) and the Canadian Network for Observational Drug Effect Studies (CNODES), building a network comprising researchers and databases from across Canada to coordinate drug safety and efficacy-based research for drugs marketed in Canada $^{33}$. These models work through an organization of the healthcare system in which data from patients are recorded during a physician consultation, linkage among pharmacy dispensing, diagnosis and other datasets occurrences resulting in a research database. Such systems allow identifying, for example, the use of contraceptive methods concomitantly to teratogenic medications and the occurrence of pregnancies ${ }^{34}$.

The relationship of databases of live births and infant deaths for analysis of congenital malformations is possible in Brazil and can be a tool for surveillance of thalidomide exposure instead of waiting for a voluntary report, which might take years to be identified ${ }^{35}$.

Brazil is the only country worldwide in which leprosy prevalence is increasing over the years ${ }^{36}$ and thalidomide will continue being prescribed. Therefore, voluntary report system and manual controls are not expected to work.

In our country, unfortunately, healthcare actions are missing, including pharmaceutical assistance management and sanitary surveillance, leading to serious consequences for the community. The gaps, when added, increase the magnitude of the risk, directing to the birth of a child with embryopathy, a serious but preventable adverse event. The classical Swiss cheese mode ${ }^{37}$ is a reality represented by TE cases. The stakeholders need to ensure the safety of patients using thalidomide, to avoid recurrences of this severe and social disease.

Through this article, we highlighted important points related to health surveillance and regulation of thalidomide exposure. Our point is an effort to reopen and keep alive the discussion that improvements are still needed to tackle such a rare condition, whose impacts for the families affected, impact the whole society.

\section{CONCLUSIONS}

Our review demonstrates that policies related to the thalidomide use have improved over the years and current regulation establishes rules for controlling its distribution, prescription, dispensing, and use, but questions remain related to their effectiveness in reducing thalidomide exposure during pregnancy. Brazilian surveillance system is manual and pharmacovigilance is supported by voluntary reports. The failure of the system to properly control the thalidomide use and its effects might lead to serious consequences to the community; therefore, this subject deserves constant attention and a proactive surveillance system. 
1. Vianna FSL, Oliveira MZ, Sanseverino MTV, Morelo EF, Rabello Neto DL, Lopez-Camelo J et al. Pharmacoepidemiology and thalidomide embryopathy surveillance in Brazil. Reprod Toxicol. 2015;53:63-7. https://doi.org/10.1016/j.reprotox.2015.03.007

2. Vianna FSL, Kowalski TW, Fraga LR, Sanseverino MTV, Schuler-Faccini $\mathrm{L}$. The impact of thalidomide use in birth defects in Brazil. Eur J Med Genet. 2017;60(1):12-5. https://doi.org/10.1016/j.ejmg.2016.09.015

3. Ministério da Saúde (BR). Portaria № 344, de 12 de maio de 1998. Aprova o regulamento técnico sobre substâncias e medicamentos sujeitos a controle especial. Diário Oficial União. May 12, 1998.

4. Agência Nacional de Vigilância Sanitária - Anvisa. Resolução RDC № 11, de 22 de março de 2011. Dispõe sobre o controle da substância talidomida e do medicamento que a contenha. Diário Oficial União. Mar 22, 2011.

5. Brasil. Lei № 10.651, de 16 de abril de 2003. Dispõe sobre o controle do uso da talidomida. Diário Oficial União. Apr 16, 2003.

6. Wiktorowicz M, Lexchin J, Moscou K, Silversides A, Eggertson L. Keeping an eye on prescription drugs, keeping canadians safe: active monitoring systems for drug safety and effectiveness in Canada and internationally. Toronto: Health Council of Canada; 2010[accessed Sep 11, 2019]. Available at: http://epe.lac-bac.gc.ca/100/200/301/hccccs/keeping_an_eye-ef/H174-21-2010-eng.pdf

7. Mota DM, Vigo A, Kuchenbecker RS. Evolução e elementoschave do sistema de farmacovigilância do Brasil: uma revisão de escopo a partir da criação da Agência Nacional de Vigilância Sanitária. Cad Saúde Pública. 2018;34(10):1-20. https://doi.org/10.1590/0102-311×00000218

8. Latin American Colaborative Study of Congenital Malformations - Eclamc. Welcome to the site from the latin american collaborative study of congenital malformations. Buenos Aires: Estudio Colaborativo Latino Americano de Malformaciones Congénitas; 2020[accessed Jan 21, 2020]. Available at: http://www.eclamc.org/eng/index.php

9. Schuler-Faccini L, Soares RCF, Sousa ACM, Maximino C, Luna E, Schwartz IVD et al. New cases of thalidomide embryopathy in Brazil. Birth Defects Res A Clin Mol Teratol. 2007;79(9):671-2. https://doi.org/10.1002/bdra.20384

10. Moro A, Invernizzi N. A tragédia da talidomida: a luta pelos direitos das vítimas e por melhor regulação de medicamentos. Hist Cienc Saúde-Manguinhos. 2017;24(3):603-22. https://doi.org/10.1590/s0104-59702017000300004

11. Rehman W, Arfons LM, Lazarus HM. The rise, fall and subsequent triumph of thalidomide: lessons learned in drug development. Ther Adv Hematol. 2011;2(5):291-308. https://doi.org/10.1177/2040620711413165

12. Oliveira MA, Bermudez JAZ, Souza ACM. Talidomida no Brasil: vigilância com responsabilidade compartilhada? Cad Saúde Pública. 1999;15(1):99-112. https://doi.org/10.1590/S0102-311X1999000100011
13. Associação Brasileira dos Portadores da Síndrome da Talidomida - ABPST. $O$ que é talidomida. São Paulo: Associação Brasileira dos Portadores da Síndrome da Talidomida; 2007[accessed Apr 9, 2019]. Available at: http://www.talidomida.org.br/oque.asp

14. Franks ME, Macpherson GR, Figg WD. Thalidomide. Lancet. 2004;363(9423):1802-11. https://doi.org/10.1016/S0140-6736(04)16308-3

15. Paumgartten FJR. Thalidomide and its analogues: comparative clinical efficacy and safety, and costeffectiveness. Cad Saúde Pública. 2014;30(4):684-6. https://doi.org/10.1590/0102-311XPE010414

16. Agência Nacional de Vigilância Sanitária - Anvisa. Resolução RDC № 50, de 11 de novembro de 2015. Dispõe sobre a atualização do anexo 3, indicações previstas para tratamento com a talidomida, da RDC № 11 , de 22 de março de 2011. Diário Oficial União. Nov 12, 2015.

17. Ministerio da Saúde (BR). Talidomida: acesso às normativas e orientações de controle. Brasília: Ministério da Saúde; 2018[accessed 2019 Sep 11]. Available at: http://www.saude.gov.br/assistencia-farmaceutica/ medicamentos-rename/cesaf/43993-talidomida

18. Ministerio da Saúde (BR). Portaria № 3.125, de 7 de outubro de 2010. Aprova as diretrizes para vigilância, atenção e controle da hanseníase. Diário Oficial União. Oct 8, 2010.

19. Ministerio da Saúde (BR). Portaria № 708, de 6 de agosto de 2015. Aprova as diretrizes diagnósticas e terapêuticas do mieloma múltiplo. Diário Oficial União. Aug 7, 2015.

20. Ministerio da Saúde (BR). Portaria № 493 , de 11 de junho de 2015. Aprova o protocolo de uso da talidomida no tratamento da síndrome mielodisplásica. Diário Oficial União. June 12, 2015.

21. Ministerio da Saúde (BR). Portaria № 298, de 21 de março de 2013. Atualiza os protocolos de uso da talidomida no tratamento da doença do enxerto contra hospedeiro e do mieloma múltiplo. Diário Oficial União. Mar 22, 2013.

22. Ministerio da Saúde (BR). Portaria № 100, de 7 de fevereiro de 2013. Aprova o protocolo clínico e diretrizes terapêuticas do lúpus eritematoso sistêmico. Diário Oficial União. Feb 8, 2013.

23. Agência Nacional de Vigilância Sanitária - Anvisa. Gestão da prescrição, dispensação e monitoramento de uso do medicamento talidomida: regulamentação atual e perspectivas. In: $16^{\circ}$ Encontro Nacional da Rede Sentinela; Brasília, Brasil. Brasília: Agência Nacional de Vigilância Sanitária; 2016[accessed Sep 28, 2019]. Available at: http://portal.anvisa.gov.br/documents/33868/5241567/9Gest\%C3\%A30+da+prescri\%C3\%A7\%C3\%A3o\%2C+dispen $\mathrm{sa} \% \mathrm{C} 3 \% \mathrm{~A} 7 \% \mathrm{C} 3 \% \mathrm{~A} 3 \mathrm{O}+\mathrm{e}+$ monitoramento+de+uso+do+m edicamento+Talidomida_+L\%C3\%9ACIA+SURITA.pdf / e7fd0964-b0a7-4573-b640-1d5c192b7a78

24. Ministério da Saúde (BR). Talidomida: orientação para o uso controlado. Brasília: Ministério da Saúde; 2014. 
25. Castilla EE, Ashton-Prolla P, Barreda-Mejia E, Brunoni D, Cavalcanti DP, Correa Neto J et al. Thalidomide, a current teratogen in South America. Teratology. 1996;54(6):273-7. https://doi.org/10.1002/ (SICI)1096-9926(199702)55:2<156::AID-TERA6>3.0.CO;2-1

26. Vianna FSL, Lopez-Camelo JS, Leite JCL, Sanseverino MTV, Dutra MG, Castilla EE et al. Epidemiological surveillance of birth defects compatible with thalidomide embryopathy in Brazil. Plos One. 2011;6(7):1-5. https://doi.org/10.1371/journal.pone.0021735

27. World Health Organization - WHO. Essential medicines and health products: embryopathy report of a meeting of experts. Geneva: World Health Organization; 2014[accessed Sep 29, 2019]. Available at: https://www.who.int/ medicines/news/thalidomide_story/en/

28. Ministerio da Saude (BR). Projeção da população do Brasil por sexo e idade simples: 2000-2060. Brasília: Ministério da Saúde; 2019[accessed Sep 28, 2019]. Available at: http://tabnet.datasus.gov.br/cgi/tabcgi. exe?ibge/cnv/projpopbr.def

29. Ministerio da Saude (BR). Distribuição do medicamento talidomida no sistema único de saúde. Brasília: Ministério da Saúde; 2019[accessed Sep 28, 2020]. Available at: https://portalarquivos2.saude.gov.br/images/pdf/2019/ marco/26/Nota-Tecnica-SEI-MS-8358704-desabastecimentotalidomida-marco-2019.pdf

30. European Comission - EC. European platform on rare disease registration. Brussels: European Comission; 2019[accessed Jan 21, 2020]. Available at: https://eu-rd-platform.jrc.ec.europa.eu
31. Centers for Disease Control and Prevetion - CDC. National center on birth defects and developmental disabilities. Washington: Centers for Disease Control and Prevetion; 2019[accessed Jan 21, 2020]. Available at: https://www.cdc.gov/ncbddd/index.html

32. US Food and Drug Administration - FDA. FDA's sentinel initiative: background. Washington: US Food and Drug Administration; 2019[accessed June 23, 2019]. Available at: http: / /www.fda.gov/safety/fdas-sentinel-initiative/ fdas-sentinel-initiative-background

33. Raj N, Fernandes S, Charyulu NR, Dubey A, Hebbar S. Postmarket surveillance: a review on key aspects and measures on the effective functioning in the context of the United Kingdom and Canada. Ther Adv Drug Saf. 2019;10:1-13. https://doi.org/10.1177/2042098619865413

34. Henry D, Dormuth C, Winquist B, Carney G, Bugden $S$, Teare $G$ et al. Occurrence of pregnancy and pregnancy outcomes during isotretinoin therapy. CMAJ. 2016;188(10):723-30. https://doi.org/10.1503/cmaj.151243

35. Guimarães ALS, Barbosa CC, Oliveira CM, Maia LTS, Bonfim CV. Relationship of databases of live births and infant deaths for analysis of congenital malformations. Rev Bras Saúde Materno Infant. 2019;19(4):917-24. https://doi.org/10.1590/1806-93042019000400010

36. Institute for Health Metrics and Evaluation - IHME. GBD compare data visualization. Seattle: Institute for Health Metrics and Evaluation; 2017[accessed Oct 16, 2017]. Available at: http://vizhub.healthdata.org/gbd-compare

37. Peltomaa K. James Reason: patient safety, human error, and swiss cheese. Qual Manag Health Care. 2012;21(1):59-63. https://doi.org/10.1097/QMH.0b013e3182418294

Author's Contribution

Leal LF, Mota DM - Conception, planning (study design), acquisition, analysis, data interpretation and writing of the work. All authors approved the final version of the work.

\section{Conflict of Interest}

Authors have no potential conflict of interest to declare, related to this study's political or financial peers and institutions. Opinions, findings, conclusions and recommendations expressed in this article are exclusively those of the authors and do not reflect the official opinion of their organizations. 